\title{
Financial-patrimonial elder abuse: an integrative review
}

\author{
Violência financeiro-patrimonial contra idosos: revisão integrativa \\ Violencia financiera-patrimonial contra la persona mayor: revisión integrativa
}

\section{Ana Maria Ribeiro dos Santos' \\ ORCID: 0000-0002-5825-5335}

Fernanda Lorrany Silva'

ORCID: 0000-0002-1148-9492

Rosalina Aparecida Partezani Rodrigues" ORCID: 0000-0001-8916-1078

Guilherme Guarino de Moura Sá' ORCID: 0000-0003-3283-2656

José Diego Marques Santos' ORCID: 0000-0001-7973-7678

Elaine Maria Leite Rangel Andrade' ORCID: 0000-0002-1772-7439

Maria Zélia Araújo Madeira' ORCID: 0000-0003-2877-2806

'Universidade Federal do Piauí. Teresina, Piauí, Brazil. "Universidade de São Paulo. Ribeirão Preto, São Paulo, Brazil.

How to cite this article: Santos AMR, Silva FL, Rodrigues RAP, Sá GGM, Santos JDM, Andrade EMLR, et al. Financial-patrimonial elder abuse: an integrative review. Rev Bras Enferm. 2019;72(Suppl 2):328-36. doi: http://dx.doi.org/10.1590/0034-7167-2018-0703

Corresponding Author: Ana Maria Ribeiro dos Santos E-mail:ana.mrsantos@gmail.com

Submission: $08-28-2018$

Approval: 10-13-2018

\section{ABSTRACT}

Objective: to analyze the available evidence in the nursing literature about financialpatrimonial elder abuse. Method: integrative review of articles indexed in the databases CINAHL, Scopus, Web of Science, LILACS and MEDLINE, from 2007 to 2017. The combination of controlled and uncontrolled descriptors was used in Portuguese, English and Spanish. Results: 15 studies developed in seven countries were included. In the thematic analysis, three categories emerged: epidemiological data, risk factors and institutions providing services to the elderly. The occurrence of this type of violence concomitantly to the other subtypes was highlighted among the most frequent. Final considerations: the literature points to important epidemiological data, risk factors and characteristics of this type of violence, including within institutions providing services to the elderly, in different countries, essential aspects for structuring and rethinking public policies for protection and appreciation of the elderly.

Descriptors: Aged; Violence; Elder Abuse; Review; Geriatric Nursing.

\section{RESUMO}

Objetivo: analisar as evidências disponíveis na literatura de enfermagem acerca da violência financeiro-patrimonial contra idosos. Método: revisão integrativa de artigos indexados nas bases de dados CINAHL, Scopus, Web of Science, LILACS e MEDLINE, no período de 2007 a 2017. Utilizou-se a combinação de descritores controlados e não controlados, nos idiomas português, inglês e espanhol. Resultados: foram incluídos 15 estudos, desenvolvidos em sete países. Na análise temática, emergiram três categorias: dados epidemiológicos, fatores de risco e instituições provedoras de serviços aos idosos. Verificou-se a ocorrência deste tipo de violência de forma concomitante aos outros subtipos, que se destacou entre as mais frequentes. Considerações finais: a literatura aponta importantes dados epidemiológicos, fatores de risco e características desse tipo de violência, inclusive dentro das instituições prestadoras de serviço a idosos, em diferentes países, aspectos essenciais para estruturar e repensar políticas públicas de proteção e valorização da pessoa idosa.

Descritores: Idoso; Violência; Maus-Tratos ao Idoso; Revisão; Enfermagem Geriátrica.

\section{RESUMEN}

Objetivo: analizar las evidencias disponibles en la literatura de enfermería acerca de la violencia financiero-patrimonial contra ancianos. Método: revisión integradora de los artículos indexados en las bases de datos CINAHL, Scopus, Web of Science, LILACS y MEDLINE desde 2007 a 2017. Se utilizó una combinación de descriptores controlados y no controlados, en portugués, Inglés y Español. Resultados: se incluyeron 15 estudios, desarrollados en siete países. En el análisis temático, surgieron tres categorías: datos epidemiológicos, factores de riesgo e instituciones proveedoras de servicios a los ancianos. Se verificó la ocurrencia de este tipo de violencia de forma concomitante a los otros subtipos, que se destacó entre las más frecuentes. Consideraciones finales: la literatura apunta importantes datos epidemiológicos, factores de riesgo y características de ese tipo de violencia, incluso dentro de las instituciones prestadoras de servicio a ancianos, en diferentes países, aspectos esenciales para estructurar y repensar políticas públicas de protección y valorización de la persona anciana.

Descriptores: Anciano; Violencia; Maltrato al Anciano; Revisión; Enfermería Geriátrica. 


\section{INTRODUCTION}

Demographic transition brought about a change in age groups, which resulted in a worldwide increase in the number of people aged 60 years or over. This increase in the number of elderly people was accompanied by a higher number of cases of elderly abuse(1).

According to the World Health Organization (WHO), using physical force or power intentionally or not, against oneself or against others, resulting in injury, omission, damage, disability or deprivation, is defined as abuse and can be physical, psychological, sexual, abandonment, neglect, self-neglect and financial or economic ${ }^{(2)}$.

Financial or economic abuse accounted for $60 \%$ of the Brazilian inquiries in police stations and/or Public Ministry in 2012. This type of abuse consists in the improper and illegal use of financial resources and patrimony of the elderly, with family disputes and crimes committed by public and private institutions interested in pensions, retirement pensions and properties ${ }^{(3)}$.

Despite the existing public policies in the country to protect the elderly, the prevalence of financial abuse in this age group accounts for $7.8 \%$ of cases of family abuse in Brazil, and the home environment is one of the main places of its occurrence ${ }^{(4)}$. Financial exploitation of the elderly, worldwide, has its data masked by other types of abuse, despite frequency and severity. The global prevalence of this abuse is estimated between $0.7 \%$ and $14.4 \%$ and suggests that the data regarding this type of abuse are still underestimated ${ }^{(5)}$.

This abuse may be related to the structural changes in the current societies, which affect family relations and the dynamics between the different roles of each person in the family and social nucleus ${ }^{(4)}$.

Elderly people who are victims faces fear of retaliation or exacerbation of abuse, guilt, shame, fear of emotional blackmail, distrust, cognitive deficit, feeling of failure, social isolation, dependency of the caregiver, belief in the naturalness of abuse. All these fears make them not to report the ill-treatment suffered ${ }^{(1)}$.

This type of abuse occurs at all socioeconomic levels, ethnicities and religions. Although literature indicates a higher incidence in males or does not present significant differences between genders, women are often more prevalent due to indirect investigation through specific cases of women abuse being frequently reported in relation to other types ${ }^{(4)}$.

The work experience of nurses is important for the detection of risk factors implicit in scenarios of financial abuse due to the nurses' capacity for judgment, demonstrating the influence of health professionals in the identification of cases of this type of abuse ${ }^{(6)}$.

Thus, investigating the financial-patrimonial abuse is relevant because it is a subject little explored by researchers and health professionals. This premise may be evidenced by the low number of Brazilian and international publications, despite the increasing rates of this kind of abuse in the world and in Brazil that affect the physical, mental and social well-being of the elderly.

Given the role of nurses in society and their commitment to prevention, maintenance and rehabilitation of health, investigating the current conjuncture on this topic will contribute to control strategies against this type of abuse, as well as to the development of protective actions and care for the elderly.

\section{OBJECTIVE}

To analyze the available evidence in the nursing literature about financial-patrimonial elder abuse.

\section{METHOD}

\section{Ethical aspects}

As it was an integrative review, the research was not submitted to the Research Ethics Committee, but the authors' ideas were used in the development of this study.

\section{Type of study}

This is an integrative review study, which consists of gathering and synthesizing results of research with different methodological approaches. For its operationalization, there were the following steps: definition of the study question; searching the databases and determining the inclusion and exclusion criteria of the studies for sample composition; definition of the information to be extracted from the selected studies; analysis of the studies that integrate the sample; interpretation of results and review report ${ }^{(7)}$.

The study question was: what is the available evidence in the nursing literature about financial-patrimonial elder abuse? It was elaborated based on the PVO strategy, by which a set of terms was defined for each element: population $(P)$, problem or variables $(V)$ and outcomes $(\mathrm{O})^{(8)}$.

In this study, the population was represented by the elderly; the problem was set up as financial-patrimonial abuse and the desired results were represented by nursing. These, in turn, guided the definition of controlled and uncontrolled terms for searching databases.

\section{Collection and organization of data}

The bibliographic survey was carried out in February 2017, through virtual access to the Latin American \& Caribbean Literature databases in Health Sciences (LILACS via VHL), Medical Literature Analysis and Retrieval System Online (MEDLINE via PubMed), Cumulative Index to Nursing and Allied Health Literature (CINAHL), Scopus and Web of Science, through the use of controlled terms (Health Sciences Descriptors (DeCS - Descritores em Ciências da Saúde), Medical Subject Headings - MeSH and CINAHL Titles) and uncontrolled (keywords), which were established according to previous readings on the topic of interest.

The articles were accessed through the journal portal of the Coordination for the Improvement of Higher Education Personnel (CAPES - Coordenação de Aperfeiçoamento de Pessoal de Nível Superior), in an area with Internet Protocol (IP) recognized at the Universidade Federal do Piauí.

In order to survey the studies, the advanced search form of each database was used, whereby the controlled and uncontrolled terms related to each element of the PVO strategy present in Chart 1, were combined. The OR Boolean connector was used and then between each set, the AND Boolean connector was used.

In order to select the publications, inclusion criteria were: primary studies addressing financial-patrimonial elder abuse, published in English, Portuguese or Spanish, in the last ten years from the search (January 2007 to February 2017). 
Chart 1 - Controlled and uncontrolled descriptors employed in the search strategy for population, problem and result, and search history in each database, 2017

\begin{tabular}{|c|c|c|}
\hline & & MEDLINE via Pubmed \\
\hline $\mathrm{P}$ & MESH & Aged; Aging; Aged, 80 and over; \\
\hline & Und & Elderly; Senescence; Oldest Old \\
\hline V & MESH & Elder Abuse; Violence \\
\hline & Und & $\begin{array}{l}\text { Financial exploitation; Elder financial abuse; Elder } \\
\text { mistreatment; Economic abuse }\end{array}$ \\
\hline $\mathrm{O}$ & MESH & Nursing care; nursing \\
\hline & $\begin{array}{l}\text { earch } \\
\text { istory }\end{array}$ & $\begin{array}{l}\text { Search (((((((aged) OR aging) OR ("aged, } 80 \text { and } \\
\text { over")) OR elderly) OR senescence) OR "oldest old")) } \\
\text { AND (((((("elder abuse") OR violence) OR"financial } \\
\text { exploitation") OR "elder financial abuse") OR "elder } \\
\text { mistreatment") OR "economic abuse")) AND (("nursing } \\
\text { care") OR nursing) }\end{array}$ \\
\hline & & CINAHL \\
\hline $\mathrm{P}$ & Titles & Aged; Aging; Aged, 80 and over \\
\hline & Und & Elderly; Senescence; Oldest Old \\
\hline V & Titles & Elder Abuse; Violence \\
\hline & Und & $\begin{array}{l}\text { Financial exploitation; Elder financial abuse; Elder } \\
\text { mistreatment; Economic abuse }\end{array}$ \\
\hline $\mathrm{O}$ & Titles & Nursing care \\
\hline & Und & Nursing \\
\hline & $\begin{array}{l}\text { earch } \\
\text { istory }\end{array}$ & $\begin{array}{l}\text { (TX aged ORTX aging ORTX ("aged, } 80 \text { and over") ORTX } \\
\text { elderly OR TX senescence ORTX"oldest old") AND (TX } \\
\text { "nursing care" OR TX nursing) AND (TX"elder abuse" ORTX } \\
\text { violence ORTX"financial exploitation"ORTX "elder financial } \\
\text { abuse" ORTX"elder mistreatment"OR TX "economic abuse") }\end{array}$ \\
\hline & & LILACS via VHL \\
\hline $\mathrm{P}$ & DECS & Aged; Aging; Aged, 80 and over \\
\hline & Und & Elderly; Senescence; Oldest Old \\
\hline V & DECS & Elder Abuse; Violence \\
\hline $\mathrm{O}$ & DECS & $\begin{array}{l}\text { Financial exploitation; Elder financial abuse; Elder } \\
\text { mistreatment; Economic abuse }\end{array}$ \\
\hline & Und & Nursing care; Nursing \\
\hline & $\begin{array}{l}\text { earch } \\
\text { istory }\end{array}$ & $\begin{array}{l}\text { (tw:((tw:((tw:(aged)) OR (tw:(aging)) OR (tw:(“aged, } \\
80 \text { and over")) OR (tw:(elderly)) OR (tw:(senescence)) } \\
\text { OR (tw:(“oldest old")))) AND (tw:((tw:(violence)) OR } \\
\text { (tw:(“elder abuse")) OR (tw:(“financial exploitation")) OR } \\
\text { (tw:(“elder financial abuse")) OR (tw:("economic abuse")) } \\
\text { OR (tw:(“elder mistreatment")))) AND (tw:((tw:(nursing)) } \\
\text { OR (tw:(“nursing care")))))) }\end{array}$ \\
\hline & & Scopus \\
\hline & $P$ & $\begin{array}{l}\text { Aged; Aging; Aged, } 80 \text { and over; Elderly; Senescence; } \\
\text { Oldest Old }\end{array}$ \\
\hline & V & $\begin{array}{l}\text { Elder Abuse; Violence; Financial exploitation; Elder } \\
\text { financial abuse; Elder mistreatment; Economic abuse }\end{array}$ \\
\hline & $\mathrm{O}$ & Nursing care; Nursing \\
\hline & $\begin{array}{l}\text { earch } \\
\text { istory }\end{array}$ & $\begin{array}{l}\text { ((TITLE-ABS-KEY (“aged") OR TITLE-ABS-KEY ("aging") } \\
\text { OR TITLE-ABS-KEY ("aged, } 80 \text { and over") OR TITLE-ABS- } \\
\text { KEY ("senescence") OR TITLE-ABS-KEY ("elderly") OR } \\
\text { TITLE-ABS-KEY ("oldest old"))) AND ((TITLE-ABS-KEY ("elder } \\
\text { abuse") OR TITLE-ABS-KEY ("violence") OR TITLE-ABS- } \\
\text { KEY ("financial exploitation") OR TITLE-ABS-KEY (“elder } \\
\text { financial abuse") OR TITLE-ABS-KEY (“elder mistreatment") } \\
\text { OR TITLE-ABS-KEY ("economic abuse"))) AND ((TITLE-ABS- } \\
\text { KEY ("nursing care") OR TITLE-ABS-KEY ("nursing"))) }\end{array}$ \\
\hline
\end{tabular}

\begin{tabular}{|c|l|}
\hline \multicolumn{2}{|c|}{ Web of Science } \\
\hline P & $\begin{array}{l}\text { Aged; Aging; Aged, 80 and over; Elderly; Senescence; } \\
\text { Oldest Old }\end{array}$ \\
\hline V & $\begin{array}{l}\text { Elder Abuse; Violence; Financial exploitation; Elder } \\
\text { financial abuse; Elder mistreatment; Economic abuse }\end{array}$ \\
\hline O & Nursing care; Nursing \\
\hline hearch & $\begin{array}{l}\text { (Topic: ("nursing care") OR Topic: (nursing)) AND (Topic: } \\
\text { ("elder abuse") OR Topic: (violence) OR Topic: ("financial } \\
\text { exploitation") OR Topic: ("elder financial abuse") OR } \\
\text { Topic: ("elder mistreatment") OR Topic: ("economic } \\
\text { abuse")) AND (Topic: (aged) OR Topic: (aging) OR Topic: } \\
\text { ("aged, 80 and over") OR Topic: (elderly) OR Topic: } \\
\text { (senescence) OR Topic: ("oldest old")) }\end{array}$ \\
\hline
\end{tabular}

Note: Und - Uncontrolled descriptors.

Book chapters, news articles, response letters, editorials, doctoral thesis, master's essays, technical reports, studies related to the other age group, literature review studies/traditional systematic or integrative review, and those selected in another database and studies that did not respond to the questioning of this research were excluded.

The search was carried out by two independent researchers, who standardized the sequence of use of the terms and crossings in the databases. The obtained results were confronted in order to ascertain the existence of difference for diagnosis and correction of possible misconception in this stage of the study.

\section{Data analysis}

There were 7,324 publications identified, of which 4,977 duplicates in the databases were considered only once, which totaled 2,347 articles for reading. Subsequently, the selection was carried out, considering initially as potentially eligible studies whose titles and abstracts reported evidence on financial-patrimonial elder abuse. After reading the abstracts and applying the inclusion criteria, 22 articles were selected for reading in full. At the end, 15 articles were included in the review sample. The study selection strategy is presented in Figure 1.

In order to construct the last step (review report), the analysis of the objectives, results and conclusions of the 15 selected articles was grouped into three categories: epidemiological data on financial-patrimonial elder abuse, risk factors for financialpatrimonial abuse, and financial abuse and institutions providing services to the elderly.

\section{RESULTS}

The studies included in the sample were published during the years 2009 ( $n=1 / 6.7 \%), 2010$ ( $n=1 / 6.7 \%), 2011(n=1 / 6.7 \%), 2012$ $(n=6 / 40.0 \%), 2014(n=2 / 13.3 \%)$ and $2016(n=1 / 6.7 \%)$ and performed in the United States America ( $n=6 / 40 \%)$, Turkey ( $n=2 / 13.3 \%)$, Australia ( $n=2 / 13.3 \%)$, Ireland ( $n=2 / 13.3 \%)$, Slovenia ( $n=1 / 6.7 \%)$, Czech Republic ( $n=1 / 6.7 \%)$ and Canada $(n=1 / 6.7 \%)$, in different journals.

The majority of the selected studies had a quantitative approach ( $n=8 / 53.4 \%)$, with a cross-sectional $(n=5 / 33.4 \%)$ and cohort $(n=3 / 20.0 \%)$ methods. The mixed approach studies also comprised the sample $(n=3 / 20.0 \%)$, as well as qualitative research $(n=4 / 26.6 \%)$. 


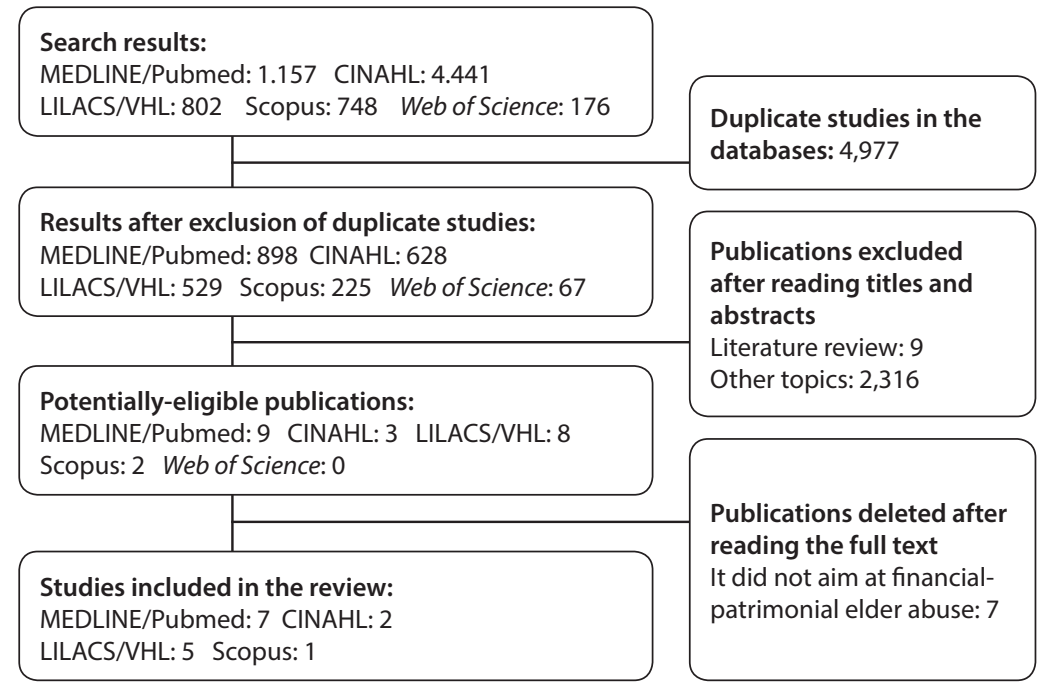

Figure 1 - Flowchart of the selection of articles included in the review, 2017

The analysis of the profile of the 15 articles integrating the present research, regarding the year, country, database, design, objectives, sample, and conclusion, is summarized in Chart 2.

Regarding the main offenders, the authors identified: family members, especially the spouses, especially when in home environment. Moreover, employees of institutions providing services to the elderly, especially directors, trusted lawyers, vendors and even the government ${ }^{(9,11-12,15-19)}$.

The main risk factors that make the elderly vulnerable to suffering this type of violence were: unemployment, low income, low social protection. Also, do not associating this type of violence with the "elder abuse"term, having impairment in Activities of Daily Living (ADLs) and Instrumental Activities of Daily Living (IAVDs). Having a family member with a strong sense of entitlement to elderly assets, feeling frightened by a relative, the elderly not knowing their rights, as well as having cognitive, physical, health, fragility and widowhood problems were also risk factors ${ }^{(9-13,16,18)}$.

The studies identified the occurrence of financial-patrimonial abuse in institutions providing care for the elderly $(n=4 / 26.7 \%)$, in the community where the elderly lived $(n=6 / 40.0 \%)$ and both $(n=1 / 6.7 \%)$. However, only seven studies have brought the prevalence of financial abuse $(n=7 / 46.7 \%)$. There was variation in the types of abuse, corresponding to $5.2 \%(10) ; 2.1 \%(11) ; 57.3 \%$ in the community and $32.8 \%$ in institutions ${ }^{(13)} ; 61.3 \%(15) ; 2.1 \%{ }^{(16)}$; $1.3 \%^{(21)} ; 21.5 \%^{(23)}$.

Chart 2 - Distribution of scientific articles according to year of publication, country, database, design, objectives, sample and conclusion of the study, 2017

\begin{tabular}{|c|c|c|c|c|}
\hline $\begin{array}{l}\text { Year/ } \\
\text { Country/ } \\
\text { Database }\end{array}$ & Outlining & Objectives & Sample & Conclusion \\
\hline $\begin{array}{l}2009 \text { Czech } \\
\text { Republic } \\
\text { VHL }{ }^{(9)}\end{array}$ & Qualitative & $\begin{array}{l}\text { To describe the experiences of elder } \\
\text { abuse experienced by residents and } \\
\text { employees of institutions for the elderly } \\
\text { practiced by the nursing team and family } \\
\text { members. }\end{array}$ & $\begin{array}{l}20 \text { elderly, } 20 \\
\text { institution employees } \\
\text { and } 2 \text { municipal } \\
\text { authority managers. }\end{array}$ & $\begin{array}{l}\text { The financial abuse suffered by the elderly } \\
\text { was practiced especially by family members, } \\
\text { influenced by internal (personal) and external } \\
\text { (professional) factors. Preventive programs } \\
\text { should address these factors. }\end{array}$ \\
\hline $\begin{array}{l}2010 \\
\text { USA } \\
\text { CINAHL }\end{array}$ & $\begin{array}{l}\text { Cross- } \\
\text { sectional }\end{array}$ & $\begin{array}{l}\text { To estimate the prevalence and } \\
\text { correlations between emotional, } \\
\text { physical, sexual and financial abuse } \\
\text { among the elderly. }\end{array}$ & 5,777 elderly. & $\begin{array}{l}\text { The correlated factor found for all types } \\
\text { investigated was low social support. }\end{array}$ \\
\hline $\begin{array}{l}2011 \\
\text { Turkey } \\
\text { PubMed }\end{array}$ & Qualitative & $\begin{array}{l}\text { To investigate the prevalence of abuse } \\
\text { and neglect of elderly living with their } \\
\text { relative and related factors. }\end{array}$ & 331 elderly. & $\begin{array}{l}\text { Abuse and neglect were prevalent in } 13.3 \% \\
\text { of the elderly. The related factors were female } \\
\text { gender, low schooling, living with spouses } \\
\text { and children, having few family relationships. }\end{array}$ \\
\hline $\begin{array}{l}2012 \\
\text { Ireland } \\
\text { PubMed }\end{array}$ & $\begin{array}{l}\text { Cross- } \\
\text { sectional }\end{array}$ & $\begin{array}{l}\text { To measure the prevalence of elder abuse } \\
\text { and neglect for } 12 \text { months and examine } \\
\text { the profile of victims and offenders. }\end{array}$ & 2,021 elderly. & $\begin{array}{l}\text { The prevalence of abuse and overall neglect } \\
\text { was } 2.2 \% \text {. The victims were women, with } \\
\text { cognitive impairment and low social } \\
\text { protection. The offenders were unemployed, } \\
\text { with some addiction (alcoholism), a physical } \\
\text { or mental health problem. }\end{array}$ \\
\hline $\begin{array}{l}2012 \\
\text { Slovenia } \\
\text { PubMed }^{(13)}\end{array}$ & $\begin{array}{l}\text { Cross- } \\
\text { sectional }\end{array}$ & $\begin{array}{l}\text { To statistically analyze whether elderly } \\
\text { care institutions protect frail elderly } \\
\text { individuals from mental, physical and } \\
\text { financial abuse. }\end{array}$ & $\begin{array}{l}\text { Elderly: } 300 \text { ( } 172 \\
\text { living in the home } \\
\text { and } 128 \text { in shelters } \\
\text { for the elderly). }\end{array}$ & $\begin{array}{l}\text { Elderly people may find better protection } \\
\text { from physical and financial abuse in } \\
\text { institutional custody. }\end{array}$ \\
\hline $\begin{array}{l}2012 \\
\text { USA } \\
\text { VHL }^{(14)}\end{array}$ & $\begin{array}{l}\text { Cross- } \\
\text { sectional }\end{array}$ & $\begin{array}{l}\text { To compare cases of financial abuse with } \\
\text { cases of elder physical abuse and the } \\
\text { dynamics of the judicial processes of } \\
\text { each case. }\end{array}$ & $\begin{array}{l}\text { Elderly who have } \\
\text { suffered financial } \\
\text { abuse: } 242 \text {. } \\
\text { Elderly who suffered } \\
\text { physical abuse: } 314 \text {. }\end{array}$ & $\begin{array}{l}\text { Most cases of financial abuse received fines as } \\
\text { a penalty, while physical abuse cases received } \\
\text { arrests and detentions. }\end{array}$ \\
\hline
\end{tabular}




\begin{tabular}{|c|c|c|c|c|}
\hline $\begin{array}{l}\text { Yearl } \\
\text { Country/ } \\
\text { Database }\end{array}$ & Outlining & Objectives & Sample & Conclusion \\
\hline $\begin{array}{l}2013 \\
\text { USA } \\
\text { PubMed }\end{array}$ & $\begin{array}{l}\text { Population- } \\
\text { based cohort }\end{array}$ & $\begin{array}{l}\text { To quantify the relationship between } \\
\text { elder abuse and the specific subtypes of } \\
\text { elder abuse and the rate of admission in } \\
\text { specialized nursing practices. }\end{array}$ & $\begin{array}{l}6,674 \text { participants in } \\
\text { the Chicago Aging } \\
\text { and Health Project. }\end{array}$ & $\begin{array}{l}\text { Elder abuse is independently associated with } \\
\text { increased admission rates and stays longer } \\
\text { than } 30 \text { days in the health service. }\end{array}$ \\
\hline $\begin{array}{l}2013 \\
\text { Ireland } \\
\text { PubMed }^{(16)}\end{array}$ & Cohort & $\begin{array}{l}\text { To describe the prevalence of five } \\
\text { types of elder abuse, compare levels of } \\
\text { consciousness, examine the relationship } \\
\text { between elder abuse experiences and } \\
\text { the characterization of the term, and the } \\
\text { relationship between knowing the term } \\
\text { and asking for help. }\end{array}$ & $\begin{array}{l}\text { Elderly living in the } \\
\text { community: } 2,021 \text {. }\end{array}$ & $\begin{array}{l}\text { Knowing the term elder abuse and/or } \\
\text { having had some experience with abusive } \\
\text { behavior has not made the person capable } \\
\text { of recognizing all kinds of abuse present in } \\
\text { their lives. Knowing abuse in general did not } \\
\text { influence the behavior of asking for help. }\end{array}$ \\
\hline $\begin{array}{l}2013 \\
\text { Australia } \\
\text { CINAHL }^{(17)}\end{array}$ & Mixed & $\begin{array}{l}\text { To analyze data from two Brazilian online } \\
\text { surveys, which examined elder abuse. }\end{array}$ & $\begin{array}{l}\text { Health services } \\
\text { providers: } 214 \\
\text { Elderly and family } \\
\text { members: } 113 \text {. }\end{array}$ & $\begin{array}{l}\text { All elderly and family members identified the } \\
\text { sense of entitlement held by a relative and } \\
\text { diminished ability as risk factors for financial } \\
\text { abuse. Many elderly were unaware of the } \\
\text { potential risks to their financial well-being. } \\
\text { Service providers have difficulties in involving } \\
\text { the elderly in preventive interventions. }\end{array}$ \\
\hline $\begin{array}{l}2013 \\
\text { USA } \\
\text { VHL }^{(18)}\end{array}$ & Qualitative & $\begin{array}{l}\text { To explore perceptions of children who } \\
\text { migrated from the urban area due to } \\
\text { lack of employment opportunities and } \\
\text { provide care to parents. }\end{array}$ & $\begin{array}{l}\text { Elderly Caregivers of } \\
\text { Southern Illinois: } 6 .\end{array}$ & $\begin{array}{l}\text { The financial exploitation of the elderly in } \\
\text { rural environments is a hidden problem. }\end{array}$ \\
\hline $\begin{array}{l}2013 \\
\text { Canada } \\
\text { PubMed }^{(19)}\end{array}$ & Qualitative & $\begin{array}{l}\text { To explore perceptions of elder abuse } \\
\text { from older people representing less- } \\
\text { either-or less-marginalized groups in } \\
\text { Canada. }\end{array}$ & $\begin{array}{l}\text { Elderly people from } \\
\text { less - or marginalized } \\
\text { groups: } 87 .\end{array}$ & $\begin{array}{l}\text { The elderly are a heterogeneous group with } \\
\text { diverse origins, concerns and vulnerabilities, } \\
\text { so it is important to consider the cultural } \\
\text { and ethnic differences and the various } \\
\text { perspectives of elder abuse. }\end{array}$ \\
\hline $\begin{array}{l}2013 \\
\text { USA } \\
\text { PubMed }^{(20)}\end{array}$ & $\begin{array}{l}\text { Cross- } \\
\text { sectional }\end{array}$ & $\begin{array}{l}\text { To identify elder abuse perpetrated by } \\
\text { Nursing aides in Assisted Livings ( } A L) \text {. }\end{array}$ & $\begin{array}{l}\text { Nurse aides who } \\
\text { worked at } A L: 832 .\end{array}$ & $\begin{array}{l}\text { Complaints at places like Assisted Livings } \\
\text { are not uncommon. It is necessary to extend } \\
\text { the institutional focus to the AL to better } \\
\text { investigate elder abuse }\end{array}$ \\
\hline $\begin{array}{l}2014 \\
\text { USA } \\
\text { VHL }^{(21)}\end{array}$ & Cohort & $\begin{array}{l}\text { To identify the prevalence of ill-treatment } \\
\text { to the elderly who received a Home Visit } \\
\text { of nurses and to determine the types of } \\
\text { elder abuse and the factors associated } \\
\text { with such maltreatment. }\end{array}$ & Elderly: 724. & $\begin{array}{l}\text { The prevalence of abuse was } 7.4 \% \text {, and } \\
\text { the types of were psychological, financial, } \\
\text { physical, sexual and negligence. Associated } \\
\text { factors were: social and family, mental and } \\
\text { physical health and the inability to perform } \\
\text { ADL and IADLs. }\end{array}$ \\
\hline $\begin{array}{l}2014 \\
\text { Australia } \\
\text { VHL }^{(22)}\end{array}$ & Mixed & $\begin{array}{l}\text { To report findings from a research project } \\
\text { funded by the Australian Research } \\
\text { Council that focused on financial abuse } \\
\text { by family members. }\end{array}$ & $\begin{array}{l}\text { Executive heads of } \\
\text { care organizations for } \\
\text { the elderly: } 228 \text {. } \\
\text { Assistance } \\
\text { professionals of these } \\
\text { institutions: } 214 \text {. }\end{array}$ & $\begin{array}{l}\text { Assistance professionals and executive heads } \\
\text { could benefit from whistleblower legislation } \\
\text { to prevent prosecution in cases where they } \\
\text { initiated research that did not produce } \\
\text { sufficient evidence for financial abuse. }\end{array}$ \\
\hline $\begin{array}{l}2016 \\
\text { Turkey } \\
\text { Scopus }^{(23)}\end{array}$ & $\begin{array}{l}\text { Cross- } \\
\text { sectional }\end{array}$ & $\begin{array}{l}\text { To determine the relationship between } \\
\text { neglect and abuse suffered by the } \\
\text { elderly and primary caregivers and the } \\
\text { experiences of overloading and abuse of } \\
\text { caregivers. }\end{array}$ & $\begin{array}{l}\text { Elderly: } 186 ; \\
\text { Caregivers: } 136 .\end{array}$ & $\begin{array}{l}\text { Abuse is a mutual relationship between the } \\
\text { elderly and caregivers, it is necessary to study } \\
\text { the burden on perpetrators of abuse. }\end{array}$ \\
\hline
\end{tabular}

\section{Epidemiological data on financial-patrimonial elder abuse}

This category deals with the epidemiological profile of financialpatrimonial elder abuse in different countries and includes studies that present the prevalence of this type of abuse, the description of the victims and main offenders.

In Ireland, the prevalence of abusive behavior experienced by people over the age of 65 was $5.9 \%{ }^{(16)}$. Financial abuse was the second most common type, reported by $2.1 \%$ of the elderly and $60 \%$ of them, reported this type of abuse to a third person, mainly to other members of the family and the police. Of the elderly, 80-90\% did not associate financial abuse with the "elder abuse"term. This shows that certain types of abuse are more easily identified than others ${ }^{(16)}$ and often this type is not considered by the elderly.

In another Irish study, authors identified financial abuse as the most frequent. Women aged 65 to 79 years were more prone when compared to men; having mental health impairment and low social support were predictors of suffering this abuse. Adult children were identified as the main offenders, followed by other relatives, spouses, friends and health professionals. Most cases occurred at the victim's home. Unemployment, addictions such 
as alcoholism, physical health problems and mental health problems or intellectual disability were described as the main characteristics of abuse perpetrators. For the most part, the occurrence was reported to another relative and the intervention most used according to the participants, another family member intervened in the situation ${ }^{(12)}$.

American scholars compared cases of financial and physical abuse and the judicial dynamics that involved each case, financially affected victims averaged 82.2 years, and were mostly women (67.7\%). Most of the financial offenders were female $(73.1 \%)$, employed mainly as auxiliaries (43.1\%), directors (26\%), among other occupations that included accountants, laundry workers, caregivers and others with $27.9 \%$ and nurses with $2 \%$. The most applied penalty to cases of financial abuse was the fine $(69.8 \%)$, and the least punished was imprisonment for conviction (12\%)(14).

In Turkey, a study with elderly and primary caregivers to determine the relationship between neglect and abuse to which elderly people were exposed by their primary caregivers and experiences of burden and aggression to caregivers found that $21.5 \%$ of the elderly and $44 \%$ of the caregivers suffered financial abuse, this type being concomitant with psychological abuse. The elderly were often the victims of their spouses. As for caregivers, most were subjected to abuse by daughters of the elderly, followed by spouses, children and daughters-in-law. Those who reported that their workload was overburdened, were more likely to financially harm their elderly relatives ${ }^{(23)}$.

A US study with 724 elderly people in primary care showed that the prevalence of financial abuse in the population was $2.6 \%$. As for the patients who reported having suffered more than one type of abuse, the financial was in $52.9 \%$ of the cases. This type of abuse was commonly associated with the child or grandchild living with the elderly, as well as children and grandchildren ${ }^{(21)}$.

Another study explored the perception of abuse by elderly people from ten marginalized groups in Canadian society and the authors noted that financial abuse was the second most mentioned type. In addition, it was identified that the main offenders were members of the family, trusted lawyers, salesmen, and the government ${ }^{(19)}$.

The authors of these studies concluded that financial-patrimonial abuse is one of the most common types that affects the elderly, however, underreporting does not present the real dimension of this problem.

\section{Risk factors for financial-patrimonial abuse}

This category presents and details the main risk factors for financial-patrimonial abuse found in the articles included in this review.

In Australia, authors identified that of the 160 service providers who answered the question about the main risk factors for the elderly suffering financial abuse by a family member, $80 \%$ cited as the main: the family member having a strong sense of entitlement to the properties or possessions of the elderly (84.4\%), the elderly had reduced capacity (81.9\%), being dependent on the care of a family member (80.6\%), fear of a family member (73.1\%), lack of knowledge of their rights (71.9\%), and family problems with alcohol and drugs (79.4\%). Of the elderly and their families, $43.2 \%$ were not concerned with the properties, finances or patrimony of the elderly, because they made a will and trusted their relatives. In addition, daughters were more likely to identify financial abuse within their families (36.7\%) and the elderly were the least likely to detect this type of aggression by a family member $(11.1 \%)^{(17)}$.

In the United States, researchers investigated perceptions of adult children who returned home from their parents in rural areas due to economic recession revealed that before the crisis, they believed that their relatives were able to take care of their finances independently. However, when they returned home they realized that they were being victims of financial exploitation. These relatives believed that the elderly became vulnerable to financial abuse for different reasons, such as cognitive problems, physical health needs, fragility and widowhood ${ }^{(18)}$.

In another American study, which sought to identify the prevalence and correlations between different types of elder abuse, the authors identified as potential risk factors: having low social protection, needing assistance for Activities of Daily Living (ADLs) and previous experience with some traumatic event ${ }^{(10)}$.

Authors of a Czech study investigating experiences of abuse in care institutions have identified as major risk factors that have influenced the occurrence of financial abuse: the elderly with a diagnosis of dementia and/or mental illness, being hostile and/ or aggressive with employees ${ }^{(9)}$.

A research that sought to identify presence of elder abuse living with a relative in a primary health care area and related factors, the authors found that being female, having low schooling and living with spouses and children were decisive for the elderly suffer this type of abuse ${ }^{(12)}$.

The authors of these studies show that the risk factors for financial-patrimonial abuse were present in different environments and permeate social, economic and functional interests, perceptions and vulnerabilities of the elderly.

\section{Financial abuse and institutions providing services to the elderly}

This category covers studies that have brought characteristics of financial abuse identified within institutions that serve the elderly, among them, health services.

Identifying assailant elder abuse resident of Assisted Livings in the United States reported that $26 \%$ of the aides reported having observed or evidenced the team destroying residents' belongings. Similarly, 3\% suspected that the staff adulterated the savings (savings) of the elderly. However, scores for the categories that made up the range of financially violent behaviors were low ${ }^{(20)}$.

Another US study, which sought to relate elder abuse to the admission rate in nursing homes, showed that of the 106 cases reported, 65 (61.3\%) were financial abuse, which was associated with physical abuse and neglect by the caregiver, increase in the length of stay for more than thirty days ${ }^{(15)}$.

The perception of service providers and the executive heads of caring institutions about financial elder abuse by family members in Australia showed that $27.8 \%$ of respondents reported this type of abuse as a common form of reported or suspected aggression. However, $70.6 \%$ stated that the institutions had specific interventions to deal with such cases, among them were 
requests for guardianship, request for research to the public defender, reporting to the police, talking to a member more concerned about the family. The difficulties reported to face cases of financial abuse were: difficulty in detection, the need for consent before taking action on the case, the risk of the family member removing the elderly from the service, lack of resources to deal with this problem ${ }^{(22)}$.

Spouses and children are the main offenders, both physically and financially, and this type represented $57.3 \%$ of the reports of the elderly living in the community and $32.8 \%$ of those living in nursing homes, which represents a low incidence in these institutions in Slovenia. It was also observed that being able to perform Activities of Daily Living (ADL) reduces the risks to suffer physical and financial abuse ${ }^{(13)}$.

In describing the experiences of abuse experienced by elderly people and employees of elderly care institutions in Czech Republic, the authors identified the financial as one of the types cited by respondents, characterized as the unauthorized use of a resident's finances by an employee or by the institution and the misappropriation of the elderly's pension by a relative ${ }^{(9)}$.

At the same time, the studies show that institutions that provide services to the elderly and develop protection and care actions may also pose risks to the financial patrimony of the elderly, according to the authors of the studies of this category, in these environments there is greater difficulty in coping with this type of abuse.

\section{DISCUSSION}

The selected studies that dealt with financial-patrimonial elder abuse were mostly from the United States, followed by other developed countries and lesser by underdeveloped, which shows that the vulnerability to this type of occurrence is present in the different socioeconomic levels ${ }^{(4)}$. Since no Brazilian studies on the subject were found, it is suggested that research on financial-patrimonial elder abuse should be developed in Brazil to support coping and prevention strategies.

Based on the main results and conclusions of the studies, aspects related to financial-patrimonial elder abuse in different countries, such as prevalence, risk factors associated with financial-patrimonial abuse, characterization of the main offenders, relationship of this kind of abuse and institutionalized elderly and factors related to interventions.

Regarding the prevalence of financial abuse, it was observed that the indices are high when compared with others. This type is, therefore, among the first three positions, which shows that this abuse is common in this age group and in different countries, and that it occurs, in most cases, simultaneously with the other types. Therefore, it can be seen that the elderly in different social, economic, cultural and ethnic contexts can be vulnerable to financial-patrimonial abuse, as well as to other types ${ }^{(9-10,14,16,19,21,23)}$.

The prevalence rates for the countries under study reinforce the need for the development of Brazilian surveys on the subject, since Brazil has an elderly population on the rise, which is often the victim of embezzlers, banks, stores and health plans or even of "saidinhas de banco" (this Brazilian expression refers to a type of crime that consists in robbery), situations in which the incapacity of assimilation of technology, lack of attention and the very fragility are exploited by these offenders, configuring as a form of abuse of concern and relevant in the country, although little studied.

The authors cited as main risk factors associated with the financial abuse suffered by the elderly: cognitive problems, health needs, fragility, widowhood, difficulties to perform Activities of Daily Living (ADLs) and Instrumental Activities of Daily Living (IADLs), being old, having low income, being a woman, living in the city and with family members ${ }^{(9-13,16,18,23)}$. Although these studies cite these factors, the need for further deepening and definition is evident, since not all studies focused on only financial abuse.

The observed risk factors contribute to the tolerance of the elderly to aggressive behaviors, due to the trust they place on people in their social cycle, which sometimes makes it difficult to recognize the abuse practiced by a family member. The degree of dependence of family members or caregivers due to the physiological changes caused by aging or to the processes of illness in this phase of life make these elderly people even more fragile and vulnerable.

This is most evident in observing that the main perpetrators cited in the articles were family members, especially spouses, sons and daughters, daughters-in-law and grandchildren, as well as family lawyers, vendors, the government and employees of institutions providing health care for the elderly. In this way, it can be seen that the relations established between these offenders and their victims favor the practice of this type of abuse, since the relatives and professionals, from whom the elderly person expects a trust relationship, can become exploiters.

A study that compared cases of physical and financial abuse, followed judicially, occurred among institutionalized elders, characterized the financial offenders as being the majority of women, who held management positions in the institution. The penalties observed in the trials of the cases followed were mostly fines, while the majority of cases of physical aggression were punished with arrests ${ }^{(14)}$.

This data allows us to infer that, the elderly living in institutions of protection are prone to be exploited financially and that, in cases related to financial abuse, they are not judged with the same rigor as the other types. This becomes relevant when realizing that financial-patrimonial abuse occurs most often, associated with other types of abuse and can cause serious damages, such as acceleration of dependencies, depression, mental illnesses, besides deprivations of rights, powers and wills of the old man.

With respect to the act of intervening in situations of financial abuse in the United States, a study that sought to identify the prevalence, associated factors and types of abuse suffered by the elderly through home visits by nurses took almost a year to identify maltreatment in the researched sample $\mathrm{e}^{(21)}$.

This shows that, before the elderly denounce or assimilate the exploitation suffered as a type of abuse, one must face intrinsic issues such as the fear of aggravation of this fact. In addition, in some cases, insecurity because of being dependent on the offender, social isolation, shame, among others, are factors that predispose the omission of data that facilitate the identification of these acts.

Knowledge about the topic of elder abuse was mentioned as a risk factor in an Irish study, which found that people who 
experienced or witnessed financial abuse and neglect did not associate this type of abuse with that term, unlike those who suffered aggression psychological or physical ${ }^{(16)}$.

It is inferred from these findings that, although people know the concepts of abuse, their types are still not well defined in practice, since recognition within their own experiences is still deficient, especially in the association of non-physical forms of abuse.

Thus, the importance of nursing in the care for the elderly victim of abuse stands out, since studies have associated high admission rates with long stays in care services, which, although considered safer for the elderly, are not exempt from being environmentally friendly for the occurrence of this abuse ${ }^{(11)}$. In this sense, the nurse can intervene from the Primary Care, with strategies that enhance the moral formation of the citizen and the valuation of the elderly person the institutions of care services for the elderly.

Therefore, the implementation of nursing interventions for the prevention of financial-patrimonial abuse, through health education aimed at the elderly population and other age groups, is urgently needed to raise awareness and recognition of abusive acts by the community and in the hospital environment. Thus, it is believed that the establishment of links with patients favors the identification of signs of exploitation, in order to program intervention actions and combat elder abuse.

\section{Study limitations}

The study is limited by the scarce number of specific publications on financial-patrimonial elder abuse, although a significant amount of studies is reported in the area of overall elder abuse. The lack of studies is more aggravating among Brazilian research, a fact that limits the analysis of this problem in Brazil.

\section{Contributions to Nursing, Health or Public Policy}

This study addresses a complex phenomenon that affects autonomy and limits the elderly and, therefore, constitutes an important health issue. This review gathered information from studies conducted in different countries, regarding the prevalence of financial-patrimonial abuse, offenders, risk factors and institutions providing services to the elderly. Such knowledge strengthens the social and political coping of this problem. Dissemination of these results draws attention to nursing researchers, and professionals who assist this population exposed to abuse still kept veiled. In addition, this topic becomes relevant to discussions, considering the aging of the world population, together with the social and health repercussions imbricated to financial-patrimonial abuse.

\section{FINAL CONSIDERATIONS}

Nursing scientific evidence analysis on financial-patrimonial abuse points to important epidemiological data, risk factors and characteristics of this type of abuse within institutions providing services to the elderly, brought about by studies in different countries and which are essential for structuring and rethinking public policies that value and protect the elderly. Moreover, the need to consider this issue in the training of health professionals is reinforced, so that they can understand this type of abuse and develop strategies for combating and coping with this problem.

The limited production of studies on the subject shows that financial-patrimonial elder abuse needs to be studied and explored in a more in-depth way. Thus, it would be possible to point out an important gap with regard to research that traverses the description of epidemiological profiles and that presents nursing interventions to address the problem.

This study makes it possible to contribute to the practices of primary care professionals who, through closer contact with families, become advocates of abuse prevention. The information analyzed strengthens and broadens the knowledge of these professionals and potentiates the search for strategies to follow up the elderly who was victim. In this way, it is added the importance of Permanent Education in the context of financial-patrimonial elder abuse prevention and the construction of assistance protocols that guide a more accurate diagnosis of this type of abuse that is still veiled in society.

\section{REFERENCES}

1. Câmara dos Deputados (BR). Brasil 2050: desafios de uma nação que envelhece [Internet]. Braślia; 2017 [cited 2017 Feb 23]. Available from: http:// www2.camara.leg.br/atividade-legislativa/comissoes/comissoes-permanentes/ce/noticias/brasil-2050-desafios-de-uma-nacao-que-envelhece

2. World Health Organization (WHO). A global response to elder abuse and neglect: building primary health care capacity to deal with the problem worldwide: main report [Internet]. Geneva:WHO; 2008 [cited 2017 Feb 23]. Available from: http://www.who.int/ageing/ publications/ELDER_DocAugust08.pdf

3. Secretaria de Direitos Humanos da Presidência da República (BR). Manual de enfrentamento da violência contra a pessoa idosa. É possível prevenir. É necessário superar [Internet]. Brasília: Secretaria de Direitos Humanos da Presidência da República; 2013 [cited 2017 Feb 23]. Available from: https://craspsicologia.files.wordpress.com/2014/06/violencia-contra-a-pessoa-idosa_miolo_para-web.pdf

4. Santana IO, Vasconcelos DC, Coutinho MPL. Prevalência da violência contra o idoso no Brasil: revisão analítica. Arq Bras Psicol [Internet]. 2016 [cited 2017 Feb 23];68(1):126-39. Available from: http://pepsic.bvsalud.org/scielo.php?script=sci_arttext\&pid=S1809-52672016000100011

5. Peterson JC, Burnes DPR, Caccamise PL, Mason A, Henderson CR Jr, Wells MT, et. al. Financial exploitation of older adults: a populationbased prevalence study. J Gen Intern Med. 2014;29(12):1615-23. doi: 10.1007/s11606-014-2946-2

6. Harriers P, Yang H, Davies M, Gilhooly M, Gilhooly K, Thompson C. Identifying and enhancing risk thresholds in the detection of elder financial abuse: a signal detection analysis of professionals' decision making. BMC Med Educ. 2014;14:1044. doi: 10.1186/s12909-014-0268-z

7. Ganong LH. Integrative reviews of nursing research. Res Nurs Health. 1987;10(1):1-11. 
8. Fram D, Marin CM, Barbosa D. Avaliação da necessidade da revisão sistemática e a pergunta do estudo. In: Barbosa D, Taminato M, Fram D, Belasco A, editores. Enfermagem baseada em evidências. São Paulo: Atheneu; 2014. p. 21-8.

9. Bužgová R, Ivanová K. Elder abuse and mistreatment in residential settings. Nurs Ethics. 2009;16(1):110-26. doi: 10.1177/0969733008097996

10. Acierno R, Hernandez MA, Amstadter AB, Resnick HS, Steve K, Muzzy W, et al. Prevalence and correlates of emotional, physical, sexual, and financial abuse and potential neglect in the United States: the National Elder Mistreatment Study. Am J Public Health. 2010;100(2):292-7. doi: 10.2105/AJPH.2009.163089

11. Kissal A, Beşer A. Elder abuse and neglect in a population offering care by a primary health care center in Izmir, Turkey. Soc Work Health Care. 2011;50(2):158-75. doi: 10.1080/00981389.2010.527570

12. Naughton C, Drennan J, Lyons I, Lafferty A, Treacy M, Phelan A, et al. Elder abuse and neglect in Ireland: results from a national prevalence survey. Age Ageing. 2012;41(1):98-103. doi: 10.1093/ageing/afr107

13. Habjanič A, Lahe D. Are frail older people less exposed to abuse in nursing homes as compared to community-based settings? Statistical analysis of Slovenian data. Arch Gerontol Geriatr. 2012;54(3):e261-70. doi: 10.1016/j.archger.2011.07.006

14. Payne BK, Strasser SM. Financial exploitation of older persons in adult care settings: comparisons to physical abuse and the justice system's response. J Elder Abuse Negl. 2012;24(3):231-50. doi: 10.1080/08946566.2011.653315

15. Dong $X$, Simon MA. Association between reported elder abuse and rates of admission to skilled nursing facilities: findings from a longitudinal population-based cohort study. Gerontology. 2013;59(5):464-72. doi: 10.1159/000351338

16. Naughton C, Drennan J, Lyons I, Lafferty A. The relationship between older people's awareness of the term elder abuse and actual experiences of elder abuse. Int Psychogeriatr. 2013;25(8):1257-66. doi: 10.1017/S1041610213000513

17. Bagshaw D, Wendt S, Zannettino L, Adams V. Financial abuse of older people by family members: views and experiences of older Australians and their family members. Aust Soc Work. 2013;66(1):86-103. doi: 10.1080/0312407X.2012.708762

18. Mukherjee D. Financial exploitation of older adults in rural settings: a family perspective. J Elder Abuse Negl. 2013;25(5):425-37. doi: $10.1080 / 08946566.2012 .751828$

19. Ploeg J, Lohfeld L, Walsh CA. What is "elder abuse"? voices from the margin: the views of underrepresented Canadian older adults. J Elder Abuse Negl. 2013;25(5):396-424. doi: 10.1080/08946566.2013.780956

20. Castle N, Beach S. Elder abuse in assisted living. J Appl Gerontol. 2013;32(2):248-67. doi: 10.1177/0733464811418094

21. Friedman B, Santos EJ, Liebel DV, Russ AJ, Conwell Y. Longitudinal prevalence and correlates of elder mistreatment among older adults receiving home visiting nursing. J Elder Abuse Negl. 2014;27(1):34-64. doi: 10.1080/08946566.2014.946193

22. Adams VM, Bagshaw D, Wendt S, Zannettino L. Financial abuse of older people by a family member: a difficult terrain for service providers in Australia. J Elder Abuse Negl. 2014;26(3):270-90. doi: 10.1080/08946566.2013.824844

23. Özcan NK, Boyacioğlu NE, Sertçelik E. Reciprocal abuse: elder neglect and abuse by primary caregivers and caregiver burden and abuse in Turkey. Arch Psychiatr Nurs. 2016;31(2):177-82. doi: 10.1016/j.apnu.2016.09.011 